\title{
INVESTIGATION OF EFFECT ON THE MECHANICAL PROPERTIES OF QUENCHING TEMPERATURE IN AA7075
}

\author{
Süleyman KILIÇ ${ }^{1, *(D)}$, İlyas KACAR ${ }^{2}$ (D), Mevlut ŞAHİN ${ }^{3}$ (D), Fahrettin ÖZTÜRK ${ }^{4}$ (D), Oğuz \\ ERDEM 5 iD
}

\author{
${ }_{1,5}^{1,5}$ Makine Mühendisliği Bölümü, Mühendislik -Mimarlık Fakültesi, Kırşehir Ahi Evran Üniversitesi, Kırşehir, Türkiye \\ ${ }^{2}$ Mekatronik Mühendisliği Bölümü, Mühendislik Fakültesi, Niğde Ömer Halisdemir Üniversitesi, Niğde, Türkiye \\ ${ }^{3}$ Mekatronik Programı, Teknik Bilimler Meslek Yüksekokulu, Niğde Ömer Halisdemir Üniversitesi, Niğde, Türkiye \\ ${ }^{4}$ Makine Mühendisliği Bölümü, Mühendislik ve Doğa Bilimleri Fakültesi, Ankara Ylldırım Beyazıt Üniversitesi, Ankara, Türkiye \\ ${ }^{4}$ TUSAŞ - Türk Havacıllk ve Uzay Sanayii AŞ, Ankara, Türkiye
}

\begin{abstract}
In this study, effect of quenching temperature on mechanical properties of Aluminum Alloy 7075 (AA7075) are investigated. Several quenching environment is tested oil $(20 \mathrm{~W} 50)$, icy water $\left(2{ }^{\circ} \mathrm{C}\right)$, water $\left(25^{\circ} \mathrm{C}\right)$, and hot water $\left(85^{\circ} \mathrm{C}\right)$. Mechanical properties of the materials are measured. X-ray diffraction analyses are also performed for each condition. Results indicated that properties at hot water quenching and oil quenching are found to be similar. It is concluded that oil quenching does not have significant effect on mechanical properties.
\end{abstract}

Keywords: AA7075, Quenching temperature, Microstructure, Mechanical properties, Aging

\section{AA7075 ALAŞIMINDA SU VERME SICAKLIKLARININ MEKANIKK ÖZELLIKLERE ETKISINIIN İNCELENMESI}

\section{ÖZET}

Bu çalışmada, 7075 Alüminyum alaşımında (AA7075) su verme sıcaklıklarının mekanik özelliklere etkisi araştırılmıştır. Su verme ortamlarından yăg $(20 \mathrm{~W} 50)$, buzlu su $\left(2{ }^{\circ} \mathrm{C}\right)$, su $\left(25^{\circ} \mathrm{C}\right)$ ve sicak su $\left(85^{\circ} \mathrm{C}\right)$ test edilmiştir. Malzemelerin mekanik özellikleri ölçülmüştür. Her bir durum için X-ray analizleri gerçekleştirilmiştir. Sonuç olarak sıcak su ve yağda su verme işlemlerinin benzer sonuçlar gösterdiği görülmüştür. Yağda su verme işleminin mekanik özellikler üzerinde önemli bir etkisi olmadığı sonucuna varılmıştır.

Anahtar kelimeler: AA7075, Su verme sıcaklığı, Mikro yapı, Mekanik özellikler, Yaşlanma

\section{INTRODUCTION}

High strength Al-Zn-Mg alloys which are categorized as 7XXX series alloys are wrought aluminum alloys [1]. They were commercially launched in 1940 by German researchers. These alloys have been widely used in aerospace industry due to their high strength, fracture toughness, and resistance to stress corrosion [2]. Their microstructures are based on the $\mathrm{Al}-\mathrm{Zn}-\mathrm{Mg}(-\mathrm{Cu})$ system. They included some distinct phases depending on cooling rate at room temperature. Many types of heat treatments have been applied on these alloys to improve mechanical properties. Heat treatments change the microstructure due to transformation of phase zones.

In a solid solution of 7075 aluminum alloy, microstructure includes dispersoids, coarse constituent particles $(\eta(\mathrm{MgZn} 2), \mathrm{T}$ $\left(\mathrm{Al}_{2} \mathrm{Mg}_{3} \mathrm{Zn}_{3}\right), \mathrm{S}\left(\mathrm{Al}_{2} \mathrm{CuMg}\right)$, etc...), fine-scale precipitates i.e. $\eta^{\prime}\left(\mathrm{MgZn}_{2}\right)$ in grain, grain boundaries or both [3-7]. While slow cooling allows precipitation of excess compounds, a rapid cooling rate doesn't allow precipitation due to lack of time. As a result, a supersaturated solid solution known as GP (Guinier-Preston) zones occurs at room temperature. Eventually, this supersaturated solution includes extremely fine dispersed precipitate particles distributed uniformly. So, its micro-structure has a specific composition and structure difficult to analyze. It is an unstable phase and has very high tendency to nucleate. At elevated temperatures it transforms meta-stable $\left(\eta^{\prime}, \mathrm{T}^{\prime}\right)$ and stable precipitations $(\eta, \mathrm{T}$ - the equilibrium stable precipitate), respectively [8]. At high temperature aging processes, hexagonal $\eta^{\prime}$ phase was formed for high $\mathrm{Zn}: \mathrm{Mg}$ ratios whereas $\mathrm{T}^{\prime}\left(\mathrm{Al}_{2} \mathrm{Mg}_{3} \mathrm{Zn}_{3}\right) \mathrm{phase}$ can be formed for low $\mathrm{Zn}: \mathrm{Mg}$ ratios [2]. 
An aging process consists of "solutionizing (dissolution), quenching, precipitation" stages, respectively. While aging carried out as a function of time at room temperature is called natural aging. If it is performed at elevated temperatures, it is named as artificial aging. In the aging process, the general sequence of precipitation of an inter-metallic alloy as seen in Figure 1 can be represented as follow:

Solid solution $\rightarrow$ Rapid Cooling $\rightarrow$ Supersaturated solid solution $\rightarrow$ GP zones $\rightarrow \eta^{\prime} \rightarrow \eta$

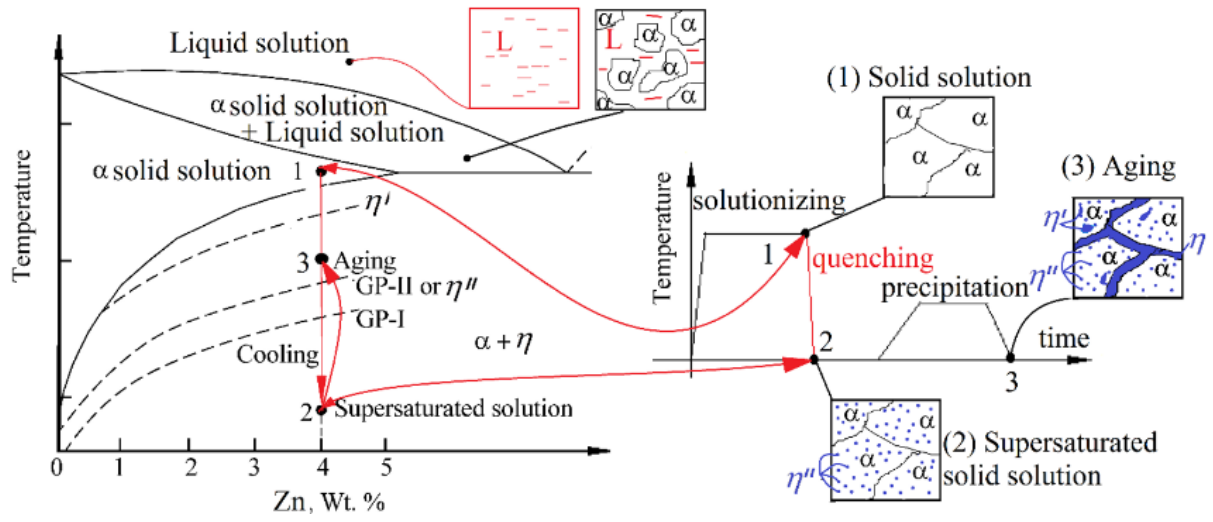

Figure 1. For aging process, Phase transformations during cooling.

In "solutionizing" stage seen as point 1 on Fig. 1, present precipitates are dissolved inside grains, an unsaturated -one phasedsolid solution is obtained. We can call this step "formatting" because it eliminates all effects of present heat treatments (if any). By dissolving, AA7075-T6 becomes just AA7075. In this stage, grains become coarser, straightening \& hardness decrease, and some recrystallization occurs.

After obtaining the dissolved structure, alloys are "quenched" very fast (point 2 on Fig. 1). In this stage, cooling operation can be performed by different coolants. The coolants used in quenching affect the mechanical properties of the material. In a study, 7075-T6 alloys with a thickness of $3 \mathrm{~mm}$ were quenched in water. hardness and strength values were higher than those cooled in air [9]. Moreover, slow quenching rate decreased the yield strength for different quenching speeds (cold water (850 $\left.\mathrm{Ks}^{-1}\right)$, hot water $\left(19 \mathrm{Ks}^{-1}\right)$ and hot water $\left.\left(7 \mathrm{Ks}^{-1}\right)\right)$ as seen in Fig. 2 [10]. In another study, highest strength values were obtained for the fast quenching rates at $20^{\circ} \mathrm{C}$ after different water temperatures $\left(20,60\right.$, and $\left.100{ }^{\circ} \mathrm{C}\right)$ [11]. Unlike these studies, icy water and oil, stress and hardness values under the condition will be examined in this study and the results will be compared. In addition, phase transformations with XRD will be involved. For large and complex parts especially with the presence of different thicknesses on the same sample, quenching is applied in the water medium with a temperature higher than $70{ }^{\circ} \mathrm{C}[12,13] . \eta$ gives stress corrosion resistance to the structure because it settled in grain boundaries first. Stress corrosion cracks were formed on the parts when cold water is used in the quenching of complex parts, [14]. Recently, water baths with polymers as quenching medium were used to minimize the residual stresses forming on the parts [13].

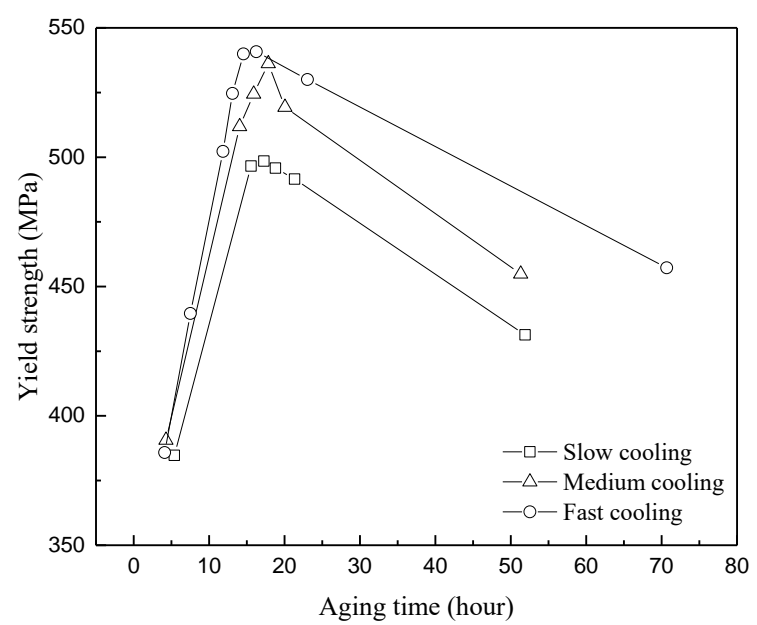

Figure 2. Effect of cooling rate on yield strength of AA7050 [10]. 
This present study examines the effects of cooling rates on the microstructural transformations and mechanical properties of AA7075.

\section{MATERIAL AND METHODS}

The material was AA7075-T6 and its chemical composition is given in Table 1. A sheet of AA7075-T6 with 2-mm thickness was taken into dissolution at $500{ }^{\circ} \mathrm{C}$ for $2 \mathrm{~h}$. At the end of the time, samples were transferred into different cooling mediums in 10 seconds for quenching. Oil $(20 \mathrm{~W} 50)$, icy water $\left(2{ }^{\circ} \mathrm{C}\right)$, normal water $\left(25^{\circ} \mathrm{C}\right)$, and hot water $\left(85^{\circ} \mathrm{C}\right)$ were used as coolant. The volume was $1 \mathrm{~m}^{3}$ of coolants so that heat can quickly be transferred. The specimens were hold inside coolant for $1 \mathrm{~h}$ after submerging. It was aimed to reach the homogenous equilibrium temperature of the samples.

The hardnesses of the samples were measured and tensile tests were carried out at a deformation rate of $25 \mathrm{~mm} / \mathrm{min}$. After tensile test, X-ray diffraction graphics of materials were obtained and microstructure photographs were taken by optical microscope. Tensile test samples were prepared according to ASTM E8 standard as shown in Fig. 3. Details of experimental conditions are listed in Table 2.

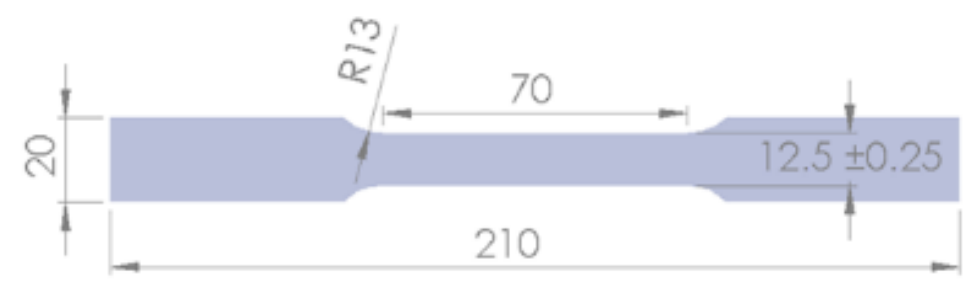

Figure 3. Dimensions of tensile test sample.

Table 1. Chemical composition of AA7075.

\begin{tabular}{ccccccccc}
\hline $\mathbf{S i}$ & $\mathbf{F e}$ & $\mathbf{C u}$ & $\mathbf{M n}$ & $\mathbf{M g}$ & $\mathbf{C r}$ & $\mathbf{Z n}$ & $\mathbf{T i}$ & $\mathbf{T i}+\mathbf{Z r}$ \\
0.07 & 0.12 & 1.5 & 0.02 & 2.6 & 0.18 & 5.8 & 0.05 & 0.08 \\
\hline
\end{tabular}

Table 2. Cooling condition of AA7075.

\begin{tabular}{cccc}
\hline Coolant & Temperature $\left({ }^{\mathbf{0}} \mathbf{C}\right)$ & Volume $\left(\mathbf{m}^{\mathbf{3}}\right)$ & Immersing time (h) \\
\hline Oil (20W50) & 25 & 1 & 1 \\
Icy water & 2 & 1 & 1 \\
Normal water & 25 & 1 & 1 \\
Hot water & 85 & 1 & 1 \\
\hline
\end{tabular}

\section{RESULTS AND DISCUSSIONS}

\subsection{X-ray Diffraction Analyses}

Material properties change microstructural phases according to its chemical composition. These phases give material's characteristic properties, such as ductile or brittle failure. X-ray diffraction tests are widely used to examine and classify atomic and molecular structure of materials, and the phases. An ideal X-ray diffraction graphic is given in Fig. 4. As can be seen from the graphic, the distance between planes, lattice parameters, crystal structure, phase quantities, defect and residual stress etc. can be easily obtained. 
S. Kılıç, İ. Kacar, M. Şahin, F. Öztürk, O. Erdem

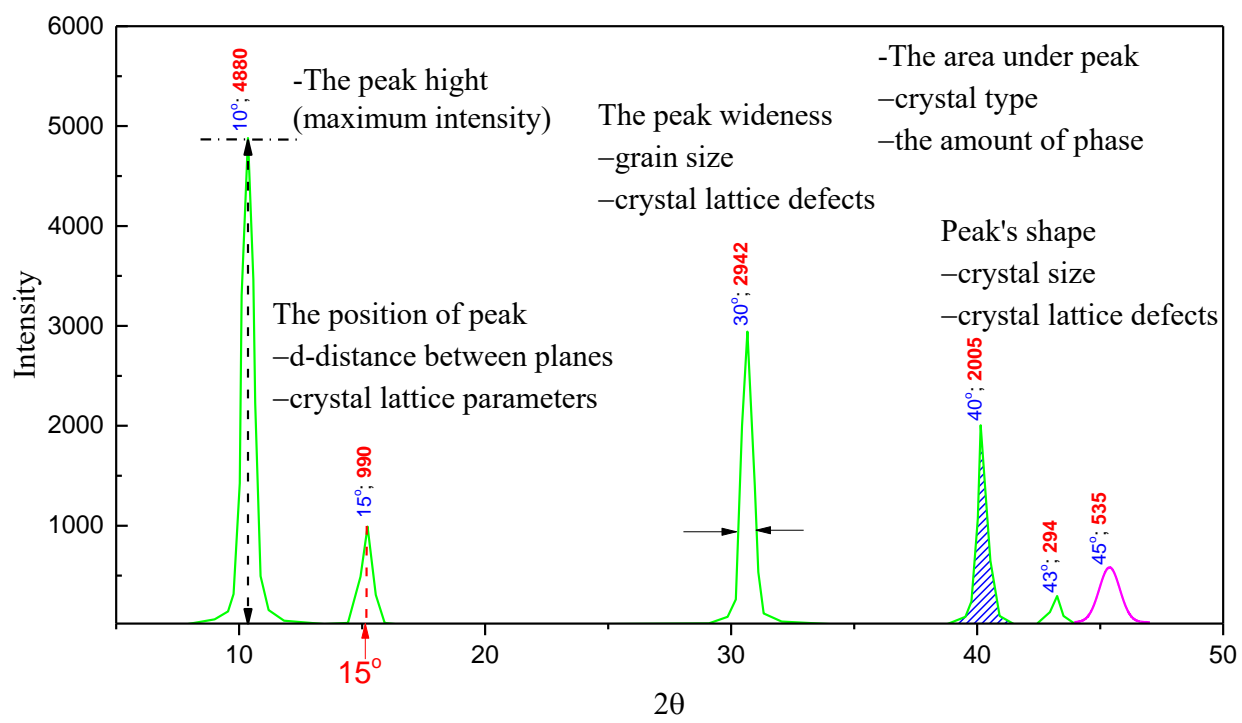

Figure 4. An ideal X-ray diffraction graphic [15].

Numerical analysis methods on curve fitting principles were used to obtain information from X-ray diffraction graphics [16-21]. One of the method is Rietveld method. Some programs were carried out numeric analysis based on Rietveld technic [22-24]. In this study, the MAUD program was used [22].

According to Fig. 5(a), it is seen that microstructure includes $\mathrm{Al}$ and $\mathrm{MgZn}_{2}\left(\eta^{\prime} / \eta\right)$ phases as expected [25, 26].

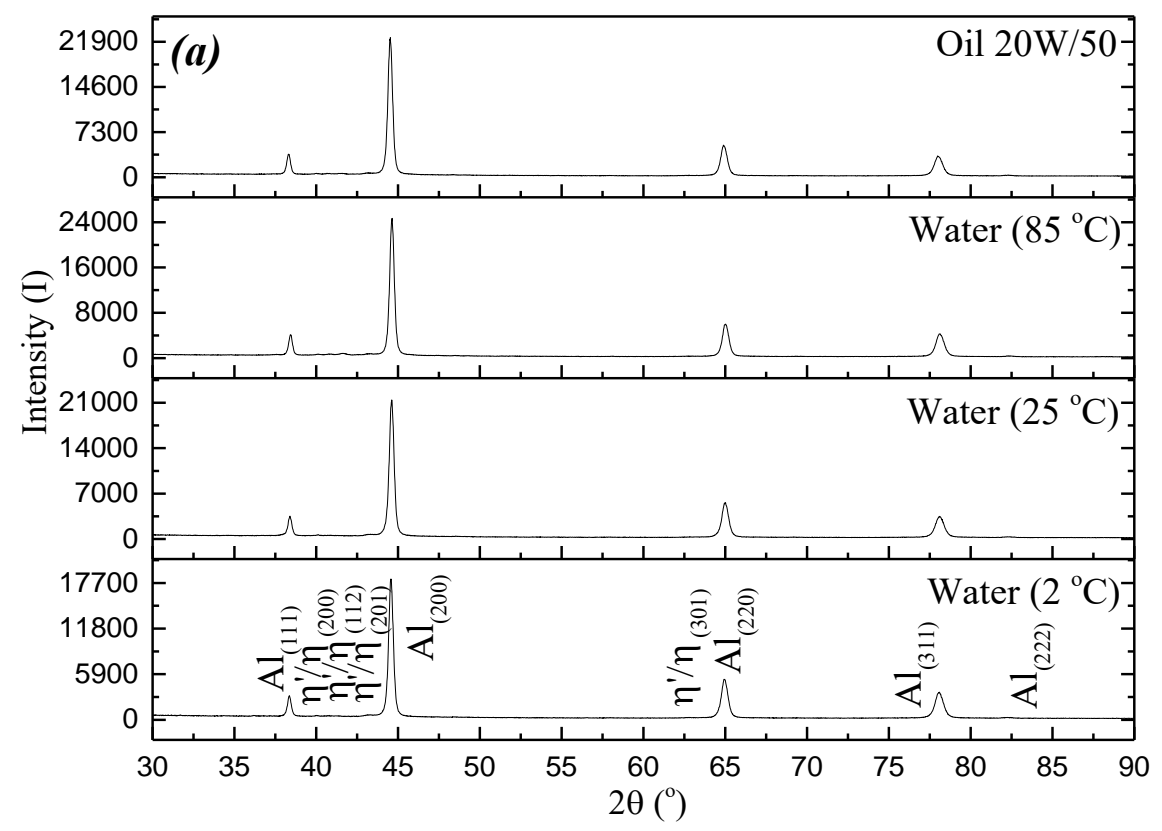




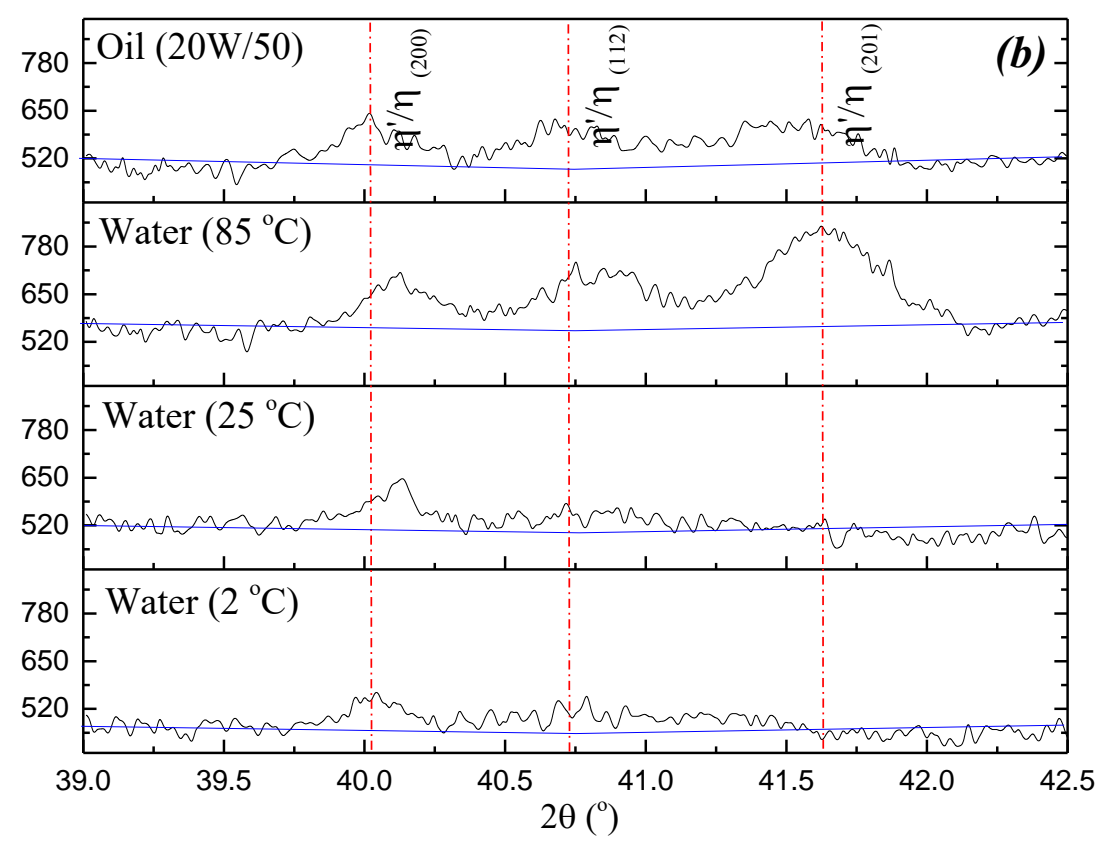

Figure 5. a) X-ray diffraction graphic of quenched AA7075 at different cooling mediums, b) Zoomed X-ray diffraction $\left(39^{\circ}-43^{\circ}\right)$.

Fig. 5(b) shows a zoomed view of region inside Fig. 5(a) to look in detail. Peaks give the type of phases. The amount of the phases is calculated from the area under the peaks.

While almost no $\mathrm{MgZn}_{2}$ phase was seen in samples quenched in water at 2 to $25^{\circ} \mathrm{C}$, relatively more $\mathrm{MgZn}_{2}$ phase is seen in samples quenched in hot water at $85^{\circ} \mathrm{C}$. However, these precipitation particles have a very small amount volume in total as seen in Fig. 5(a).

\subsection{Optical Microscope Analysis}

The specimens were prepared using epoxy resin as binding material for X-ray diffraction analyses quenched samples. After curing of epoxy-resin glue; flattening and etching steps were carried out, respectively. Struers Labopol-5 model automatic polishing machine was used for flattening step. Grinding and polishing stages were carried out on behalf of flattening. In the grinding stage, sandpapers made of SiC and magnetite dust in 320, 500, 1200, 2400, and 4000 grids were used. During grinding, tap water was used as coolant to prevent any micro-structural change which may occur as a result frictional heat. In the polishing stage, diamond suspensions on different grain sizes were used by placing polishing fabric. The diamond suspension consists of alumina paste suspensions having $3 \mu \mathrm{m}, 1 \mu \mathrm{m}, 0.25 \mu \mathrm{m}$ sizes, respectively. Separate polishing fabrics were used for application of each diamond suspension during polishing.

Keller's reagent was used for the etching step in the recipe of $1.0 \mathrm{~mL} \mathrm{HF}, 1.5 \mathrm{~mL} \mathrm{HCl}, 2.5 \mathrm{~mL} \mathrm{HNO}_{3}$, and $95.0 \mathrm{~mL} \mathrm{H} \mathrm{H}_{2} \mathrm{O}$. Etching time was 8 seconds. Photographs were taken by Olympus BX-51 optical microscope with different lenses (x5, x10, x20, $\mathrm{x} 50$, x100). In Fig. 6, grain sizes are finer in samples cooled in hot water at $85^{\circ} \mathrm{C}$ and oil at room temperature. From photographs obtained optical microscope, the $\mathrm{MgZn}_{2}$ phase cannot be seen because the phase's precipitations are too small to see by an optical microscope. 
S. Kılıç, I. Kacar, M. Şahin, F. Öztürk, O. Erdem
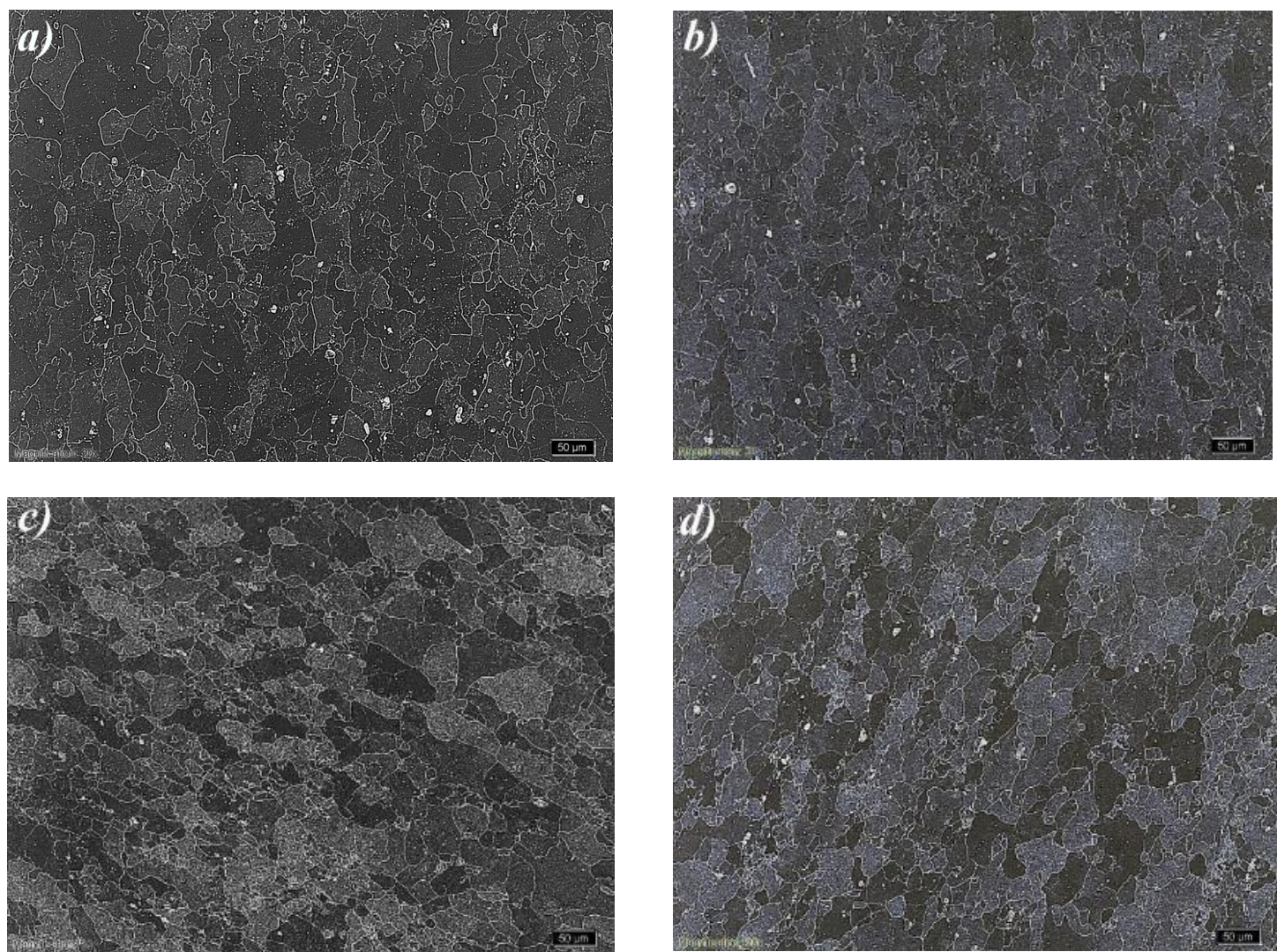

Figure 6. Optical microscope images, a) Icy $\left(2{ }^{\circ} \mathrm{C}\right)$, b) Water $\left(25^{\circ} \mathrm{C}\right)$, c) Water $\left(85^{\circ} \mathrm{C}\right)$, d) Oil $(10 \mathrm{~W} 40)$ at room temperature.

\subsection{Tensile Test}

In Fig. 7(a), the best values were obtained from the sample cooled in water at room temperature. Mechanical properties of the samples cooled in $85^{\circ} \mathrm{C}$ water are slightly smaller than others. This is caused by getting increased grain sizes of $\mathrm{MgZn}_{2}$ precipitates as a result of slow cooling. Relatively coarse grains can lead to moderate strengthening. In rapid cooling, the $\mathrm{MgZn}_{2}$ phase does not occur because rapid cooling provides too small cooling time to precipitate of $\mathrm{Mg}$ and $\mathrm{Zn}$ inter metallic phase [5, 8]. In Fig. 5(a), the increment of $\mathrm{MgZn}_{2}$ phase in the structure causes a decrease in strength.

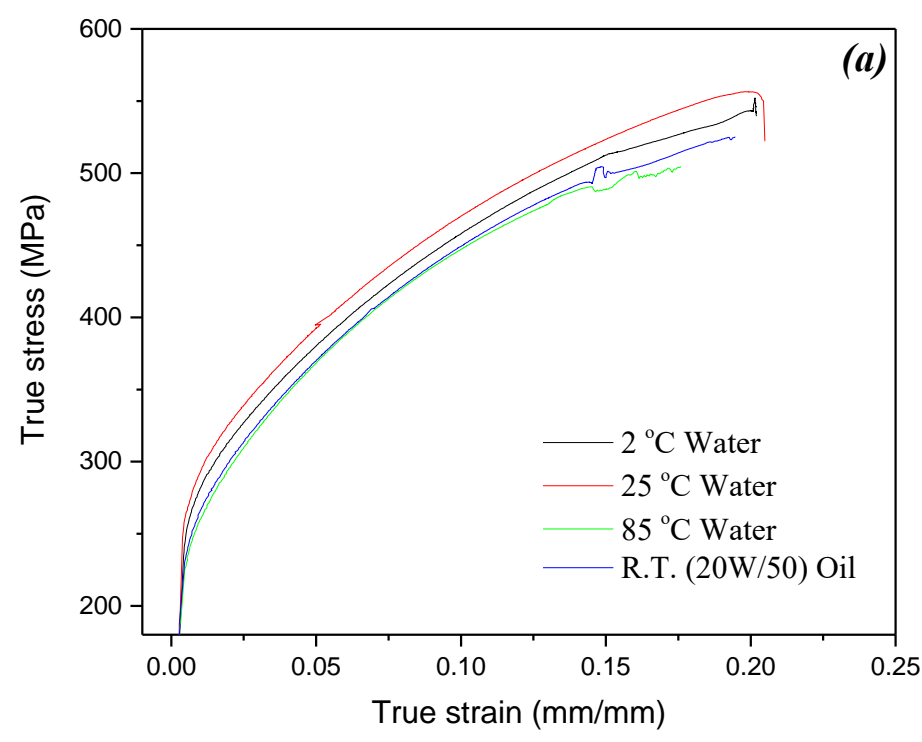




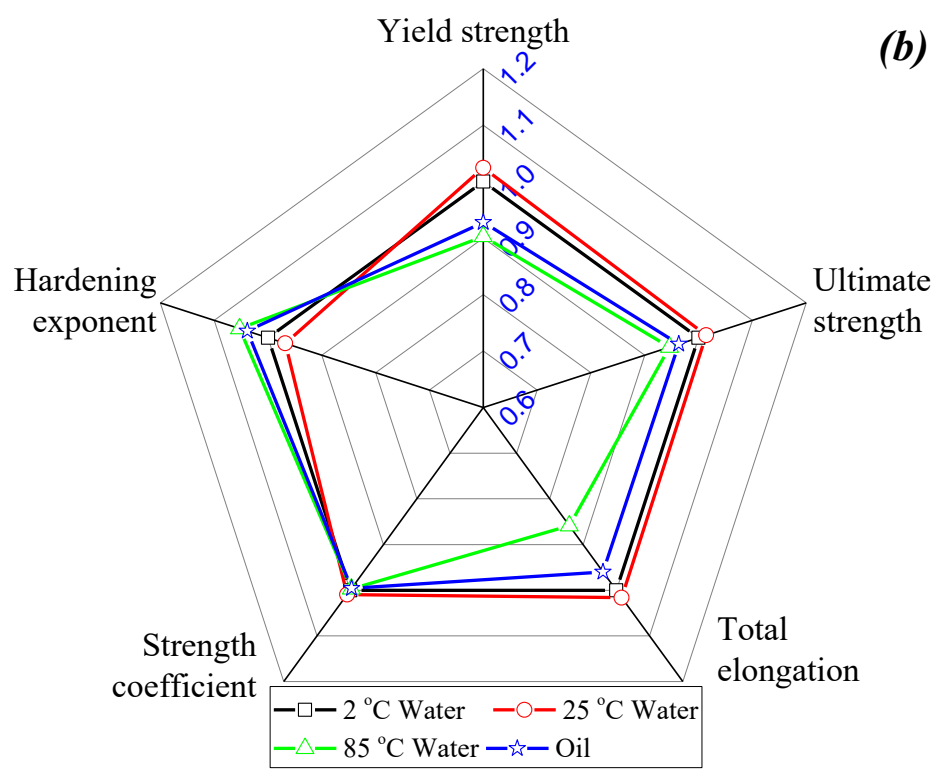

Figure 7. a) Effects of different quenching temperatures on stress-strain behaviors, b) Effects of different quenching temperatures on mechanical properties.

Highest values of yield and tensile strengths were obtained after quenching the samples in $25^{\circ} \mathrm{C}$ water, and then $2{ }^{\circ} \mathrm{C}$ water, oil, and $85^{\circ} \mathrm{C}$ water, respectively (Fig. 7b). Results reveal that quenching at different temperatures affect mechanical properties. The experimental data obtained in Table 3 is shown. Here K: strength coefficient, n: hardening exponent.

Table 3. Mechanical properties of AA7075.

\begin{tabular}{ccccc}
\hline Properties & $\mathbf{2}^{\mathbf{}} \mathbf{C}$ Water & $\mathbf{2 5}^{\mathbf{}} \mathbf{C}$ Water & $\mathbf{8 5}^{\mathbf{}} \mathbf{C}$ Water & Oil \\
\hline Yield S. (MPa) & 263.2 & 269.6 & 237.6 & 244.2 \\
Ultimate S. (MPa) & 552.1 & 556.5 & 504.4 & 525.2 \\
Total Elongation & 0.2019 & 0.2049 & 0.1758 & 0.1946 \\
K & 792.1 & 799.4 & 789.5 & 788.8 \\
n & 0.2370 & 0.2294 & 0.2495 & 0.2461 \\
\hline
\end{tabular}

\subsection{Hardness Measurements}

Hardness measurements were carried out in the Vickers hardness tester by applying a $10 \mathrm{~kg}$ load for 15 seconds. While the hardness of AA7075-T6 material was measured as $194 \mathrm{HV}$, the hardness of sample cooled in water at room temperature after dissolution decreases to $131 \mathrm{HV}$ (Fig. 8).

The hardness values of samples cooled in $2^{\circ} \mathrm{C}$ water, $85^{\circ} \mathrm{C}$ water and oil are closer to each other as expected from the tensile tests. These values are lower than those cooled in the water at room temperature. 
S. Kılıç, İ. Kacar, M. Şahin, F. Öztürk, O. Erdem

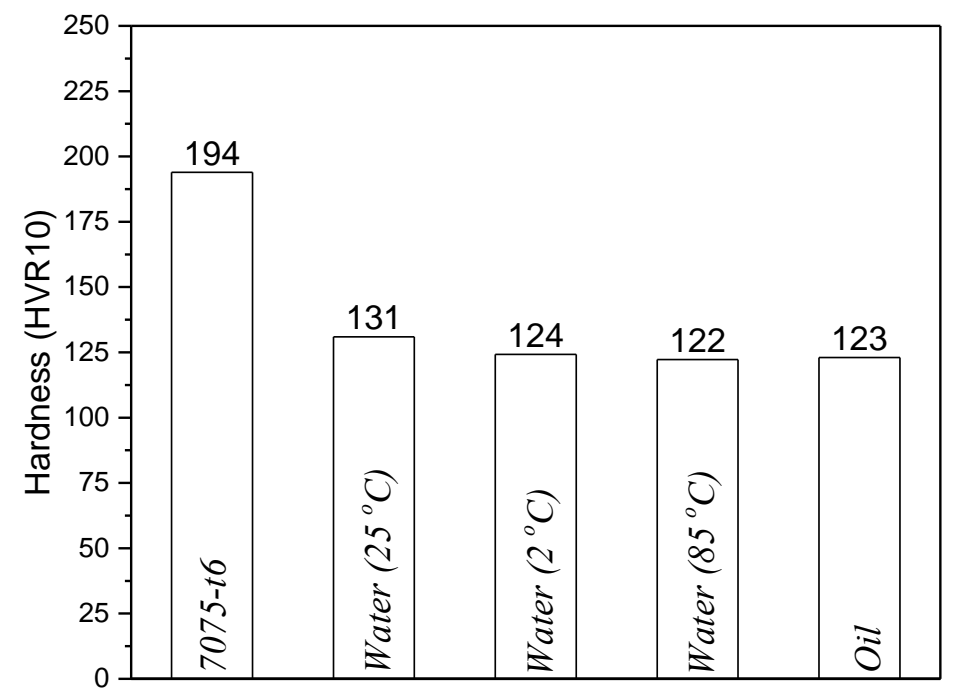

Figure 8. Effects of different quenching temperatures on hardness.

\subsection{Straightening Curves}

Straightening curves were drawn by strength/hardness versus temperature/aging duration. They help designers to select suitable temperature and durations easily. Fig. 9(a) gives a straightening curve drawn by strength versus temperature. Similarly, Fig. 9(b) gives a straightening curve drawn by hardness versus temperature. As seen, the peak value is obtained at room temperature in water quenching for AA7075.

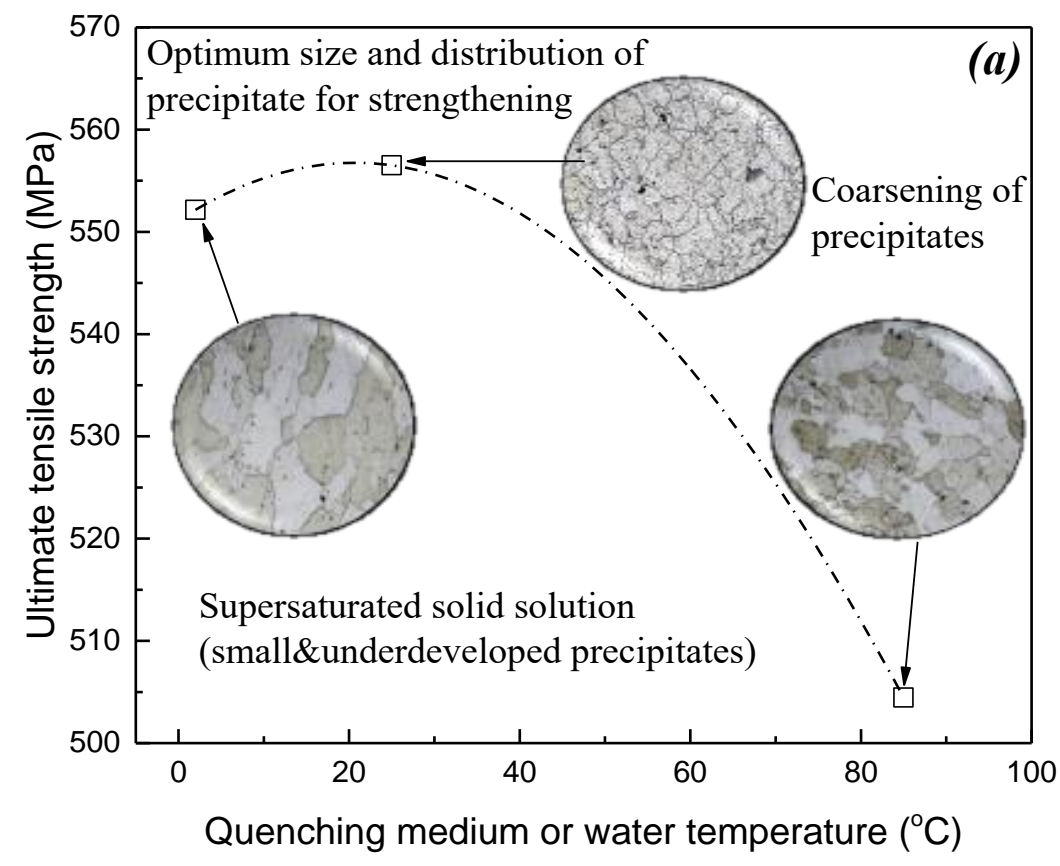




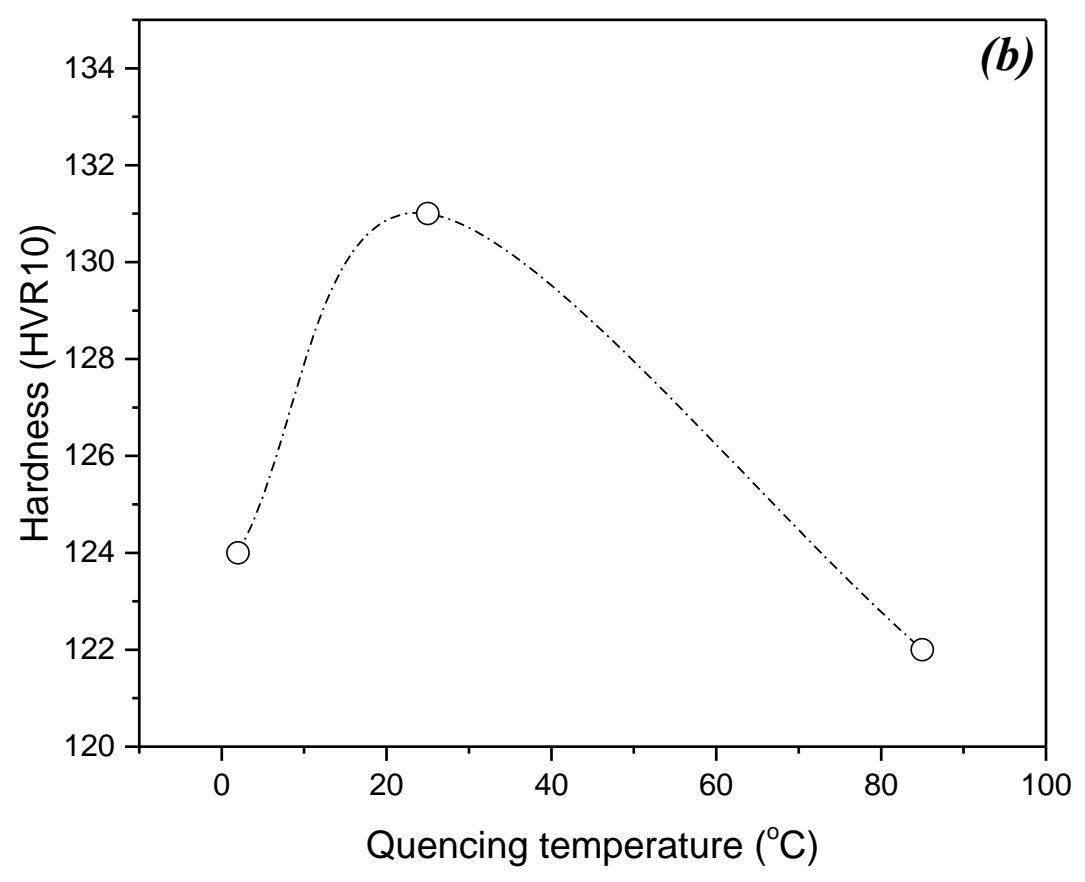

Figure 9. a) Correlation of structures and strength AA7075, (b) Correlation of structures and hardness AA7075.

\section{CONCLUSIONS} drawn:

In this study, effect of quenching medium on mechanical properties of AA7075 was investigated. Following results were

- The mechanical properties from samples cooled in $2^{\circ} \mathrm{C}$ water are worse than those from samples cooled in water at room temperature. Cooling below room temperature did not result in good properties, the mechanical properties were even decreased.

- The results obtained in water at elevated temperatures and in oil at room temperature were very similar. It was pointed out that oil quenching did not have significant effect on mechanical properties.

- The best mechanical property was observed for the sample quenched in $25^{\circ} \mathrm{C}$ water.

- Straightening curve for AA7075 alloy was obtained for different temperatures.

\section{ACKNOWLEDGEMENT}

This work was supported by Ahi Evran University, Scientific Research Projects Coordination Unit. Project Number: MMF.A3.17.001. We would like to thank the Scientific Research Coordination Unit for their financial support.

\section{REFERENCES}

[1] J. T. Staley, "History of wrought-aluminium-alloy development," in Aluminium Alloys: Contemporary Research and Applications, Treaties on Materials Science and Technology, vol. 31, R. D. D. A. K. Vasudevan, Ed. Pennsylvania: Alcoa Technical Center, 2012, pp. 3-31.

[2] A. K. Vasudevan and R. D. Doherty, Aluminum Alloys-Contemporary Research and Applications: Contemporary Research and Applications. England: Elsevier, 1989.

[3] C. Mondal and A. K. Mukhopadhyay, "On the nature of T(A12Mg3Zn3) and $\mathrm{S}(\mathrm{Al} 2 \mathrm{CuMg})$ phases present in as-cast and annealed 7055 aluminum alloy," Materials Science and Engineering: A, vol. 391, no. 1, pp. 367-376, 2005. 
[4] A. Lalpour, A. Soltanipour, and K. Farmanesh, "Effect of Friction Stir Processing on the Microstructure and Superplasticity of 7075 Aluminum Alloy," in 5th International Biennial Conference on Ultrafine Grained and Nanostructured Materials (UFGNSM15) Tehran, Iran, 2015, pp. 1-6.

[5] X.-G. Fan, D.-M. Jiang, Q.-C. Meng, B.-Y. Zhang, and W. Tao, "Evolution of eutectic structures in Al-Zn-Mg-Cu alloys during heat treatment," Transactions of Nonferrous Metals Society of China, vol. 16, no. 3, pp. 577-581, 2006.

[6] S. T. Lim, I. S. Eun, and S. W. Nam, "Control of equilibrium phases (M, T, S) in the modified aluminum alloy 7175 for thick forging applications," Materials Transactions, vol. 44, no. 1, pp. 181-187, 2003.

[7] B. Binesh and A. K. Mehrdad, "Phase evolution and mechanical behavior of the semi-solid SIMA processed 7075 aluminum alloy," Metals, vol. 6, no. 3, p. 42, 2016.

[8] D. Ozyürek, R. Yılmaz, and E. Kibar, "The effects of retrogression parameters in RRA treatment on tensile strength of 7075 aluminium alloys," Journal of the Faculty of Engineering and Architecture of Gazi University, vol. 27, no. 1, pp. 193-203, 2012.

[9] R. Clark et al., "On the correlation of mechanical and physical properties of 7075-T6 Al alloy," Engineering Failure Analysis, vol. 12, no. 4, pp. 520-526, 2005/08/01/ 2005.

[10] D. Dumont, A. Deschamps, and Y. Brechet, "On the relationship between microstructure, strength and toughness in AA7050 aluminum alloy," Materials Science and Engineering: A, vol. 356, no. 1, pp. 326-336, 2003/09/15/ 2003.

[11] A. T. Güner, Effect of quenching temperature on mechanical properties of semi-solid forming aluminum alloys (Institute of Science and Technology). Pamukkale University, 2013.

[12] B. Oğuz, Demir dışı metallerin kaynağı (OERLIKON yayını). 1990, pp. 1-23.

[13] C. Demir, E. B. Mentese, and M. A. Togay, "Alüminyum ısıl işleminde su verme uygulamaları ve kalıntı gerilme etkisi," Componenta doktas, 2017.

[14] I. Polmear, D. John, J.-F. Nie, and M. Qian, Light alloys: metallurgy of the light metals. Butterworth-Heinemann, 2017.

[15] S. Kilic and F. Ozturk, "Evaluation of Mathematical Models Performances in XRD Analysis for Determination of Volumetric Ratios of Phases," in 1st International Mediterranean Science and Engineering Congress (IMSEC), Adana, Turkey, 2016.

[16] H. Moumen1, S. Alleg, C. Djebbar1, F. Z. Bentayeb, and J. M. Greneche, "Synthesis and characterisation of nanostructured FeCo alloys," Journal of Materials Science, journal article vol. 39, no. 16, pp. 5441-5443, 2004.

[17] S. Mehdaoui et al., "Study of the properties of CuInSe2 materials prepared from nanoparticle powder," Materials Characterization, vol. 60, no. 5, pp. 451-455, 5// 2009.

[18] N. Benslim et al., "XRD and TEM characterizations of the mechanically alloyed CuIn0.5Ga0.5Se2 powders," Journal of Alloys and Compounds, vol. 489, no. 2, pp. 437-440, 1/21/ 2010.

[19] G. Dini, A. Najafizadeh, S. M. Monir-Vaghefi, and R. Ueji, "Grain size effect on the martensite formation in a highmanganese TWIP steel by the Rietveld method," Journal of Materials Science \& Technology, vol. 26, no. 2, pp. 181186, 2010.

[20] A. E. Karpikhin et al., "Structure of hydroxyapatite powders prepared through dicalcium phosphate dihydrate hydrolysis," Inorganic Materials, journal article vol. 52, no. 2, pp. 170-175, 2016.

[21]Z. K. Heiba, M. B. Mohamed, and A. M. Wahba, "Effect of Mo substitution on structural and magnetic properties of Zinc ferrite nanoparticles," Journal of Molecular Structure, vol. 1108, pp. 347-351, 3/15/ 2016.

[22] http://maud.radiographema.eu/. (2017, January 2017).

[23] http://profex.doebelin.org/. (2017, January 2017).

[24] https://www.ill.eu/sites/fullprof/. (2017, January 2017).

[25] A. Pastor and H. G. Svoboda, "Time-evolution of heat affected zone (HAZ) of friction stir welds of AA7075-T651," Journal of Materials Physics and Chemistry, vol. 1, no. 4, pp. 58-64, 2013.

[26] R. H. Oskouei, M. R. Barati, and R. N. Ibrahim, "Surface characterizations of fretting fatigue damage in aluminum alloy 7075-T6 clamped joints: the beneficial role of Ni-P coatings," Materials, vol. 9, no. 3, p. 141, 2016. 